NBER WORKING PAPER SERIES

BULL AND BEAR MARKETS IN THE TWENTIETH CENTURY

Robert B. Barsky

J. Bradford De Long

Working Paper No. 3171

NATIONAL BUREAU OF ECONOMIC RESEARCH

1050 Massachusetts Avenue

Cambridge, MA 02138

November 1989

This paper is part of NBER's research program in Financial Markets and Monetary Economics. Any opinions expressed are those of the authors not those of the National Bureau of Economic Research. 
NBER Working Paper \#3171

November 1989

\title{
BULL AND BEAR MARKETS IN THE TWENTIETH CENTURY
}

\begin{abstract}
The major bull and bear markets of this century have suggested to many that large decade-to-decade stock market swings reflect irrational "fads and fashions" that periodically sweep investors. We argue instead that investors have perceived significant shifts in the long-run mean rate of future dividend growth. and that stock prices depend sufficiently sensitively on expectations about the underlying future growth rate that these perceived shifts would plausibly generate large swings like those of the twentieth century. We go on to document that analysts who have often been viewed as "smart money" held assessments of fundamental values based on their perceptions of future economic growth and technological progress: the judgments of these analysts, like the assessments of fundamentals we generate from simple dividend growth forecasting rules, track the major decade-to-decade swings in the market rather closely.
\end{abstract}

Robert B. Barsky Department of Economics University of Michigan Ann Arbor, MI 48109-1220

\author{
J. Bradford De Long \\ Harvard University and \\ NBER \\ 1050 Massachusetts Avenue \\ Cambridge, MA 02138
}


Figure 1 plots the twentieth century course of the U.S. stock market, as given by the logarithm of the real value of the Standard \& Poor's composite index. ${ }^{1}$ The stock market is volatile on a month-to-month, year-to-year, and especially decade-to-decade scale: major bull and bear movements give the ten-year real percentage changes in the S\&P index a variance of 0.374 -a standard deviation of more than sixty percent. By contrast, the variance of ten-year real percentage changes in national product is only 0.034 . This ten-fold disparity in volatility is surprising. for a broad portfolio of stocks carries ownership of a broad share of the economy. Since the productivity of the underlying assets has grown smoothly, one would expect the value of the claims to ownership of those assets traded on the stock exchange to have grown smoothly as well.

Such volatility might be accounted for by the fact that stocks are a leveraged claim to only a special fraction of output. But as Robert Shiller has stressed, stock prices appear to be particularly volatile relative to their underlying fundamental value-the present value of the future dividends that will be paid out. Figure 2 plots the log of real January stock prices alongside the log of the ex post present value of future dividends paid, both detrended by a thirty-year moving average of past dividends. ${ }^{3}$ The present value of future dividends is nearly a constant relative to the moving average of past dividends. Major long-run stock price fluctuations, however-episodes like the major bull markets of 1949-66 or 1921-9 and the major bear markets like 1929-1933 or 1973-5-are larger than, and appear unconnected to, fluctuations in realized fundamental values.

A view taken by observers of the stock market from John Maynard Keynes and John Kenneth Galbraith to Robert Sobel and Robert Shiller is that these large swings in stock prices are due to the "animal spirits" of investors. They do not reflect large shifts in the expected present value of future dividends as assessed by a cautious and far-sighted investor. ${ }^{4}$ From this perspective. the stock market boomed in the 1920's not so much because of a perception of improved prospects for future earnings and dividends as because of the flow of new money into the stock market driven by the "fads and fashions" of uninformed new investors.

Sobel, for example, dismisses "fundamentalist" accounts by arguing that "had prices reflected "realities, the great upward move [of 1949-66] would have begun during the war," and asserts that 
the post-WWII bull was not driven by good news about future growth but sprang primarily from the erosion of the memory of 1929, which had "taken on an almost mythological quality [with] Herber Hoover... in the role of George III": and secondarily from Charles Merrill's "draw[ing]... new capital...from people of moderate incomes." Merrill brought "Wall Street to Main Street-and... use[d] the efficient. mass-merchandising methods of the chain store to do it."

An altemative view is that while irrational waves of enthusiasm or pessimism can push stock index prices away from fundamental values in a short run of months or years, in the long run (decade-to-decade) informed investors shift their money in response to changing fundamentals. If stocks become too expensive. careful investors will reduce demand by shifting their wealth out of the market and entrepreneurs will increase supply by taking more corporations public. Smart money will keep proportional differences between market prices and fundamental values from growing wider indefinitely. while shifts in fundamental valuations will cumulate. ${ }^{6}$ Shifts in fundamentals will therefore account for a larger fraction of return variability as the horizon at which returns are examined increases. Perhaps "noise" in stock prices has a sufficiently shor life span that the decade-to-decade swings that make up the major bull and bear markets predominantly reflect large shifts in businesses' prospects. ${ }^{7}$

These conflicting interpretations of major bull and bear markets have different implications for assessing the performance of the stock market as a social capital allocation mechanism. High stock markets encourage investment. The central reason to have a stock market is that it serves as a social calculating machine that reports to firms what the market thinks of their future prospects. and so governs the allocation of investment. If major swings in stock prices are driven by fads the market is unlikely to perform well. If major swings are driven by shifts in the best guess of future cash flow prospects, the verdict may be more optimistic. ${ }^{8}$

The volatility of stock market indices has always been a powerful argument for the "fads and fashions" view. Supporters of the "fundamentals" view have been hard pressed to point out the shifts in aggregate prospects that would support large bull and bear revaluations of the worth of America's corporations. As Robert Shiller put the challenge: 
the picture [figure 2]... is evidence... that a model that attributes all the variance of aggregate stock prices to fashions or fads is certainly at least as consistent with the data as is the efficient markets model. ...[I]t is hard to see how a model that makes [the fundamental value of the market] roughly a trend with $p$ [actual prices] bounced around this trend by fashions or fads could ever be rejected... in favor of a model that says that price movements anticipated dividends. Many people...suppose that...stock price movements really do forecast dividends.... This might...have been [shown]...if... [the ex post fundamental value] moved around a lot and were substantially correlated with $\mathrm{p}$ [as|...would be expected to happen... if people have a lot of information about future dividend movements. If figure [2] did happen to come out that way. we could say that it presents impressive evidence for the efficient markets theory. It did not. We should not be hesitant to mention fads or fashions as the true source of the bulk of price movements that characterize the aggregate stock market. ${ }^{9}$

We try to answer this challenge. We argue that major bull and bear markets can be seen as driven by shifts in assessments of fundamentals. We argue that investors had little knowledge of crucial factors. in particular the long-run dividend growth rate. In our view, investors changing expectations of average dividend growth plausibly lie behind the major swings of this century.

We make our argument in two steps. First, we set out a simple model of how investors might try to forecast future dividend growth and show that the stock market might then exhibit large swings like those actually seen. If the long-run rate of future dividend growth is sufficiently uncertain. investors forecasts of fundamental values would naturally have led to bull and bear swings like those actually seen. Second, we consider actual expectations held by prominent observers who placed emphasis on understanding fundamentals. We show that some careful investors focusing on fundamentals held expectations of future growth that validated large swings in stock prices. Analysts examining fundamentals whom we would classify as "smart money" formed forecasts that validated major market swings. While we cannot disprove the hypothesis that large stock 
price swings have been driven by irrational fads. we conclude that if placed in the shoes of those past investors aiming to forecast fundamentals we would have priced the market similarly. Therefore we conclude that it is at least plausible to regard the large decade-to-decade swings in the past century's stock prices as a consequence of revised forecasts of fundamentals.

\section{DETERMINING FUNDAMENTAL VALUES}

An investor who expects real dividends $D_{t}$ to grow in the future at a constant rate $g_{t}$ and who discounts the future at a long-run real required rate of retum $r_{t}$, will be willing to buy stocks if: ${ }^{10}$

$$
P_{1}=\frac{D_{1}}{r_{1}-g_{1}}
$$

Since the average price/dividend ratio over the past century is not far from twenty. $\mathrm{r}_{\mathrm{t}^{-}} \mathrm{g}_{\mathrm{t}}$ is approximately 0.05. A one percentage point increase in $g_{t}$ leads to a twenty-five percent increase in $P_{t} / D_{t}$. This sensitivity of equity values to expectations of the future dividend growth rate underlies our argument that we should expect to see large bull and bear swings.

An equivalent representation of (1), writing $p_{t}$ and $d_{t}$ for the natural logarithms of the levels of prices and dividends $P_{t}$ and $D_{t}$, is:

$$
p_{t}=d_{t}-\ln \left(r_{t}-g_{t}\right)
$$

We imagine that investors know the current dividend and the risk and time discount factors that they require. However, the average long-run rate of future dividend growth $g_{t}$ must be estimated.

A natural way for investors to estimate expected future dividend growth $g_{t}$ is to take the experience of the past and project it into the future-to do something like take the past average of dividend growth since the beginning of the stock exchange. However, when we today try to forecast the average rate of dividend growth in the future, we don't pay a lot of attention to what the rate of dividend growth was a century ago. We would be astonished if the average long-run rate of dividend growth had been the same in the Gilded Age as it is today. When we form forecasts, we reasonably act as though the recent past is more relevant for the future than the distant 
past. Therefore a reasonable rule of thumb is to take an average of past dividend growth rates that places more weight on the recent past, like:"

$$
g_{1}=(1-\theta) \sum_{i=0}^{\infty} \theta^{i} \Delta d_{t-1} \quad 0<\theta<1
$$

In general, $\theta$ should be near one. Since the long-run average rate of growth shifts only slowly and most year-to-year variation in dividend growth is transitory, the weights placed on past years should decline slowly as well. On reflection it is hard to see how an investor would forecast the long-run rate of dividend growth without using some rule of thumb like (3), presumably amplified by the addition of other forecasting variables. The natural way to determine what the average rate of future dividend growth will be is to look at what the average growth rate has been.

As figure 3 shows, the year-to-year rate of dividend growth has become less volatile over the course of the century as the American economy has matured. As the uncertainty associated with future dividend payments has decreased, the rate at which investors discount these future dividend payments has presumably decreased as well. It therefore seems appropriate to allow for a downward time trend in the rate of return investors use to discount future dividends $r_{t}$ :

$$
r_{t}=r_{1900}-\delta t
$$

We have arrived at a simple model of stock index prices. It contains three equations: Equation (4) describes the possible evolution of investors' rate of discount. Equation (3) gives the rule of thumb investors use to forecast future dividend growth. Equation (2) describes how investors process their expectations of dividend growth and their rate of discount to arrive at the price at which they are willing to buy or sell stocks. ${ }^{12}$

Estimated parameters are reported in table 1, which reports summary statistics for the fitted model comparing actual January prices to fitted January prices, using as a benchmark the ex post present value of dividends subsequently paid. Figure 4 plots actual real prices for every month alongside the prices fitted by the model for each January. The fit achieved by the model appears good. Although formal tests of hypotheses cannot be easily performed because the deviations of 
prices from fitted values are not independent-this year's gap between actual and fitted prices is highly correlated with next year's-the model accounts for a large share of the variance of prices about the actual present value of realized future dividends. The model accounts for 71 percent of the variance of January stock index prices about their ex post fundamental values, and for more than half-55 percent -of the variance in the price/dividend ratio. About half of the variance in realized annual returns could be accounted for by dividend "news" along the lines of our model. ${ }^{13}$

The estimated $\theta$ that the market acts as if it uses is about 0.97 . This is sufficiently high as to make the market slow to change its expectations of future dividend growth. Growth during the preceding decade receives a weight of $1 / 4$ in constructing today's estimate: years more than a decade in the past receive an aggregate weight of $3 / 4$. The model looks far back $\vdots$ ito the pisi is building its estimate of the future rate of growth of dividends. and it does not at first glance appear easy to argue that a value of 0.97 for $\theta$ is too sensitive to transitory booms and depressions to un derlie a careful analysis of fundamentals.

Figure 4 thus shows that the long swings in stock prices can be accounted for by swings in expectations of fundamentals. If our specification of the rule of thumb used by investors in estimating dividend growth is correct, then major market movements have been closely connected to fundamentals and represent shifts in careful fundamentals-based assessments of the values of stocks.

We have, of course, not presented anything close to a complete characterization of stock prices. Our specification of fundamentals implies that they change only slowly: yet monthly stock prices undergo jagged short-run fluctuations. Fundamental news according to our model's specification accounts for only half of the variance of annual returns and for only a small fraction of month-to-month movements. ${ }^{14}$

\section{INVESTORS' EXPECTATIONS AND STOCK PRICES: BULL MARKETS}

To say that over the twentieth century the stock market is very volatile in the long-run is more or less equivalent to saying that the past century has seen five large revaluations of the S\&P composite portfolio: five major bull and bear markets. The stock market drops by 60 percent in real value over the 1914-1918 World War I period, rises by 500 percent in real value in the 1920 's, 
drops by 75 percent in the slide that opens the Great Depression, rises by 400 percent in the sustained bull market from the early fifties to the middle sixties, and drops by 60 percent again during the OPEC/inflation crash of the mid-1970's.

In each of these major bull and bear markets the simple rule of thumb of the previous section. with weight $\theta=0.97$. would have led careful investors fundamental-based assessments of stock market values to undergo similar swings. ${ }^{15}$ In this section we argue that a number of those investors and analysts who made fundamental-based assessments of stock market values did, in each case, significantly revise their estimates of fundamentals and thus arrive at the conclusion that the new levels of the market were about right.

The first major swing we examine is the rapid runup of stock prices in the 1920's. The expectations we focus on are those held by Yale monetary economist, investor. and stock market analyst Irving Fisher at the beginning of 1930 . Irving Fisher's views of the stock market in the $1920^{\circ} \mathrm{s}$ have been ridiculed bv many, including John Kenneth Galbraith. Fisher had declared early in 1929 that stock prices had reached a "permanently high plateau." Standard histories like Sobel's see the $1920^{\circ} \mathrm{s}$ as a decade dominated by speculation, and argue that the stock market had depared far from fundamental values during the decade. ${ }^{16}$ Such histories find Fisher along with other economists like Joseph Lawrence and Charles Dice attractive targets to mock, especially in view of Fisher's declaration on the eve of Black Thursday that "any fears that the price level of stocks might go down to where it was in 1923 or earlier is not justified by present economic conditions. $" 17$

After the fall 1929 Crash. during the first half of the month of December 1929, Fisher wrote a book entitled The Stock Market Crash-and After in which he argued that the declines of October 1929 did not signal further large declines in the stock market. ${ }^{18}$ In Fisher's view, the market at the end of 1929 was fairly priced given underlying fundamentals. If Fisher`s book is read without reference to our knowledge that the Depression had begun, the arguments he advances for the sustainability of the January 1930 level of real stock prices appear sound and convincing. Fisher presents a number of reasons that investors paying the prices of stocks in January 1930 should earn acceptable returns. First, the 1920's had seen substantial exploitation of economies of scale resulting 
from mergers. Second. the application of science and invention to industry had resulted in an acceleration of productivity growth in the 1920's. Third on Fisher's list comes the development and application of scientific management. Fourth comes the shift of labor from a confrontational to a cooperative strategy of relating to management. Fifth comes Fisher's belief that Prohibition would, by decreasing addiction to alcohol, increase productivity. And sixth comes the increase in economic growth induced by the Federal Reserve's successful stabilization of the price level.

From any perspective except one that uses hindsight to anticipate the approaching Depression, Fisher's arguments appear reasonable. Price/dividend ratios were only a bit higher at the end of the $1920^{\circ}$ s than they had been between 1900 and 1910. Economic growth appeared strong. Although rapid growth could have been regarded as a transitional post-war phenomenon, Fisher's arguments that the systematic application of research and development to industry, the growth of scientific management. and the success of the "American system" of labor relations at taming unions and providing both high wages and high productivity had permanently raised the rate of U.S. economic growth in the $1920^{\circ}$ s. $^{19}$

In retrospect, we see the "New Era" of the 1920 "s as brief and without foundation. But Fisher like many others thought that the 1920's revealed that the economy had shifted to a new régime of rapid growth. His estimate of the long-run growth rate of the economy, and thus of dividends, was higher in 1929 than in 1924. Given this upward revision, his willingness to pay high prices for stocks does not seem surprising. And he might have been right to do so: anyone in 1956 who sold out in anticipation of the rapid end of that postwar boom made a mistake.

Fisher was not exceptional. The bull market of the $1920^{\circ} \mathrm{s}$ had in the eyes of contemporaries ample support from the growth of the American economy. ${ }^{20}$ Charles Dice's New Levels in the Stock Market, for example, expressly argued that stock market levels in the late 1920's were too low: in his view the market had not yet caught up with the ongoing triple revolutions in production, distribution, and finance that were steadily raising the fundamental value of American industry. As financial analyst George Woodruff put it, writing at the end of the 1930's:

In 1928 and $1929 \ldots$ the investor might read articles and books and listen to ad- 
dresses, the theme of which was the new era of prosperity.... Now, in retrospect the prices of 1929 appear fantastic.... But let the investor place himself in 1928-9 and... blot out... later years. He will know... [i] that following World War I the United States received large shipments of gold... [ii] that... active measures were concerted... to forestall... inflation... [iii] that... the United States tumed almost ovemight from a debtor into a creditor [nation].... And [iv] he will look back upon... seven years... of general prosperity.... These things together will seem to spell New Era." ${ }^{.21}$

Even Roger Babson, the only prominent forecaster to anticipate a market break in 1929, ${ }^{22}$ had been bullish as late as the end of 1928 and was again bullish in $1930 .^{23}$

Just as the 1920's were seen as a "New Era" of permanent high growth, so the 1960's also appeared a time in which the United States had made major steps toward solving its economic problems. Here we focus on analyst Benjamin Graham because of his well-deserved reputation as an extremely cautious and risk averse investor, and because of his belief in the 1960's that prices in the $1920^{\circ} \mathrm{s}$ had been unjustified. Graham acquired his reputation as an investor and an analyst by virtue of his keen eye for an undervalued company, and his firmest principle was that a prudent investor should only purchase firms with good prospects that were selling at or below liquidation value. ${ }^{24}$ Other strategies might be profitable, but they were "speculation," not investment. Yet in spite of his innate caution and conservativism and his strong belief that stock markets were prone to periods of speculative overenthusiasm, he was not willing to judge the market in the early $1960^{\circ} \mathrm{s}$ as overvalued.

Graham was of two minds in the early 1960's. Price/earnings ratios were at levels that had foretold bear markets in the past. ${ }^{25}$ And at the end of the $1940^{\circ}$ s Graham had argued that a simple "market timing" strategy of buying when stocks were low relative to a long-run moving average of past earnings and selling when stocks rose would have outperformed a buy and hold strategy. ${ }^{26} \mathrm{By}$ 1962. however. Graham knew that any such attempt to anticipate mean reversion in stock prices would have been unprofitable in the post-World War II period: such an investor would have been 
out of the market while it tripled in real value. He therefore abandoned the belief that investors should be anticipating a crash, arguing instead that the situation was one of uncertainty: "old standards of valuation are no longer applicable, and new standards have yet to be tested in time." He argued that changes in the economic policy régime made it rational for investors to pay higher multiples for stocks in the $19600^{\circ} \mathrm{s}$ than in the $1940^{\circ} \mathrm{s}, 1930^{\circ} \mathrm{s}$, or $1920^{\circ} \mathrm{s}^{27} \mathrm{He}$ :

believe[d] it reasonable to adopt a somewhat more generous approach to the valuation of common stocks than appeared justified in our previous edition. This conclusion is based on the assurance-not formerly present-of massive Federal intervention to preven. a serious business depression. This now appears to be a basic tenet of both political parties.

In Graham's estimation, the willingness of the government to tolerate inflation in order to avoid severe depression had increased the expected long-run growth rate of the economy. Interruptions of capital accumulation and large gaps between actual and potential output like those seen in the 1930's were no longer likely. In view of this increase in the expected growth rate of the economy, a rational investor should be willing to pay a higher price/dividend or price/earnings multiple for common stocks. This point of view was common. Many analysts wrote that while "old timers say stocks selling for more than ten times eamings are overpriced... this view is outmoded. The proper ratio... [is] around fifteen or sixteen times. ${ }^{* 28}$ And Roger Babson's successors echoed Irving Fisher in listing seven reasons why the post-WWII "new era" would continue indefinitely."

\section{INVESTORS' EXPECTATIONS AND STOCK PRICES: BEAR MARKETS}

The first of the major bear swings in the stock market is the collapse of real values during World War I. Figure 5 shows that this major swing in real values alone cannot be seen in the nominal stock price series. It arises entirely from the rapid inflation of World War I. Many including. most recently, Herschel Grossman have argued that ${ }^{30}$ investors during World War I expected govemments to substantially defiate the economy after the war. Anticipated postwar deflation carries 
with it an expectation of very high future real interest rates. and so the low real price of stocks during the war does not strike us as surprising or in need of explanation in terms of investors' expectations of future profits and dividends.

The second large bear market-the fall in the stock market during the Great Contraction of 1929-1933-also does not appear to bein need of explanation. The Great Depression was an unprecedented collapse of the American economy. It came as a surprise: no one had been expecting a depression of such magnitude. ${ }^{31}$ It is difficult to say what investors' expectations should have been and how they should have valued the stock market at the bottom of the Depression. We can say little about how investors should react to economic events off the scale of previous experience.

One common response was to wonder whether the Depression heralded permament stagnation. A common theme in investment literature during the 1930's became the question of whether United States economic growth was more or less played out. As one analyst put it. a "major investment problem is presented by the question whether the U.S. has. after decades of dynamic expansion. reached the stage of economic maturity. ${ }^{32}$ He concluded that it had. and that while economic maturity "does not mean that we have already ceased to grow... we are quite certain to grow less rapidly." in striking contrast to the New Era beliefs current only three years before. ${ }^{33}$ Given that one major piece of the value of stocks had always been the underlying dynamic growth of the American economy, ${ }^{34}$ the coming of economic maturity would inevitably make stocks worth less. This mood lasted through the war. One analyst in 1948 felt it necessary to "caution against the assumption that... secular growth... will necessarily find reflection in a long-term rising trend of stock prices," and forecast a gradual stock market decline over the following decade. ${ }^{35}$ And in the literature of professional economists, the same theme echoed as "secular stagnation."

The final bear market-the Oil/Inflation bear market of the 1970 's--is sufficiently recent to be familiar. The stock market fell steeply in response to the failure of the Nixon administration's price control policies and to the shocks administered by the breakdown of Bretton Woods and the rise of OPEC. During 1973 and 1974 the S\&P 500 declined by 55 percent in real terms. Fundamentalbased interpretations of this steep decline were common in the late 1970's. One that stressed investors' revisions of their expectations of future prospects was put forward by Andrew Tobias: 
The ability of stocks to outperform bonds-and to beat inflation-[in the pre1973 period]... had much to do with America's more or less steadily improving productivity.... [But t]he world has changed. Resources are scarcer: foreign competition is stronger: businesses are more highly regulated... confidence in the future, and hence investment, is not what it was: inflation lurks.... ${ }^{37}$

As a result of this recognition that the new dimensions of political economy promised by Keynesians in the 1960 's had come to an end, ${ }^{38}$ the market severely reduced its valuation of stock indices during 1973 and 1974. As Tobias went on to argue, the fact that future growth is likely to be slow did not mean that investments in common stocks were to be avoided, for "the market knows all these things..." and had consequently marked the prices of stocks down to levels at which they once again promised attractive long-run, albeit risky, returns.

The analysts cited-Fisher. Graham, Tobias, and the others-reassessed their own estimates of future prospects, and thus of the appropriate prices for stocks, in tandem with the major bull and bear swings of the market. They based their assessments on fundamentals, not on speculative dynamics: none of them adrocated buying stocks at prices above fundamentals on the theory that someone less informed would be willing to pay even more tomorrow. To the extent that these analysts' views are representative of "smart money," the major bull and bear swings reflect shifts in the best estimate of fundamentals and not the irrational fad-driven "animal spirits" of the crowd.

Are the analysts cited representative? We cannot guarantee that they are representative smart money investors. But we can say that they are representative of those who (i) made fundamentalbased as opposed to "chartist" assessments of values, ${ }^{39}$ and (ii) wrote books on investment strategy subsequently acquired by Harvard's libraries. Moreover, their judgments were shared by many of the leading economists of the day. Milton Friedman and Anna Schwartz, for example, speak of the 1920 's as the "high tide of the Federal Reserve System," when economists and central banic,rs believed that the Federal Reserve's ability to control the money supply and the rate of interest had effectively eliminated the business cyle. ${ }^{40}$ Popular worries that U.S. growth had been permanently 
derailed in the 1930 's found their echo in economists" doctrines of "secular stagnation." And Graham's belief that strong growth justified high price/dividend ratios in the early 1960's is but a pale shadow of the optimism of $1960^{\circ}$ ' Keynesians. If large fluctuations are driven by fashions and fads, then so are economists forecasts. Economists. therefore, have little warrant for concluding that the stock market's performance falls short: anyone who does critique the stock market as a forecaster faces the burden of finding an alternative procedure that would have done better.

\section{CONCLUSION}

The U.S. stock market has seen five major bull and bear markets in the twentieth century. In each case, such a large revaluation of the worth of America's companies would also have been made by any investor uncertain of the possibly-changing long-run dividend growth rate who estimated it by extrapolating the recent past. Such large revluations were also made by investment analysts who were prominent in their day, whose acumen we respect, and who concentrated on fundamental values. Our conclusion is that there is a good case that major stock market movements arise predominantly from careful reevaluations of fundamentals, and only a weaker case that "fads and fashions [are]...the... source of the bulk of price movements," as far as the large decade-to-decade major swings are concerned.

It is a fact that over the past century major market movements have been reversed more often than not. The belief that the postwar period was a "New Era" proved ex post to be correct after World War II, but not after World War I. Fears of secular stagnation in the 1930 's were too pessimistic in retrospect, as were fears in the late 1970's that the U.S. was headed for Latin Americanstyle political gridlock and economic collapse. ${ }^{41} \mathrm{~A}$ case can be made that the market-and its analysts, and the conventional wisdom of economists-overreacts, and that things are never as good as they seem in a boom or as bad as they seem in a depression.

But a look at comparative economic growth over the past century goes a way toward dispelling this possibility. Among the set of developed or rapidly developing nations in 1870, some-like Great Britain and Australia-have seen per capita income grow slowly: others-like Sweden, the U.S., and Canada-have seen per capita income grow rapidly. The post-World War II period 
shows an equal spread of national growth rates. Figure 6 plots average per capita income growth rates over the 1950-80 period for sixty-two countries. The differences between Uruguay and West Germany. Chile and Spain, or Sri Lanka and Taiwan have been much more than sufficient to drive shifts in valuation like those of the major bull and bear swings the U.S. has seen. ${ }^{42}$

Given this range of outcomes, it is understandable for investors at times to fear that whatever happened to British or Australian growth-let alone to Uruguayan-might happen here. Conversely, the tremendous surge in economic growth of the industrial revolution suggests that a further surge-an increase in per capita income growth from two to two and a half percent per year, say-might be attainable with a properly-managed high-pressure economy. Such fears and hopes could easily sustain the major bull and bear swings of the past century. And the comparative growth experience of the past century suggests that such fears are not fantastic but realistic.

Our tentative conclusion, therefore-which we reach even though the New Era of the 1920's came to a rapid end and even though secular stagnation did not begin in the 1930 s-is that major stock market movements arose not because investors' susceptibility to fads and fashions made the market excessively volatile, but because the future always appeared uncertain, and stock prices are extremely sensitive to expectations of what future growth will be. If this conclusion is correct, one implication is that the case against Wall Street-the belief that stock market speculation materially retards American economic growth-must focus on the short run volatility of the market and its effect on investors' discount rates and firms' investment plans. For the long-run volatility of the major bull and bear swings then springs not from the poor performance of Wall Street but from unavoidable uncertainties about future economic growth. 
FIGURE 1

REAL U.S. STOCK INDEX PRICES, 1900-1988

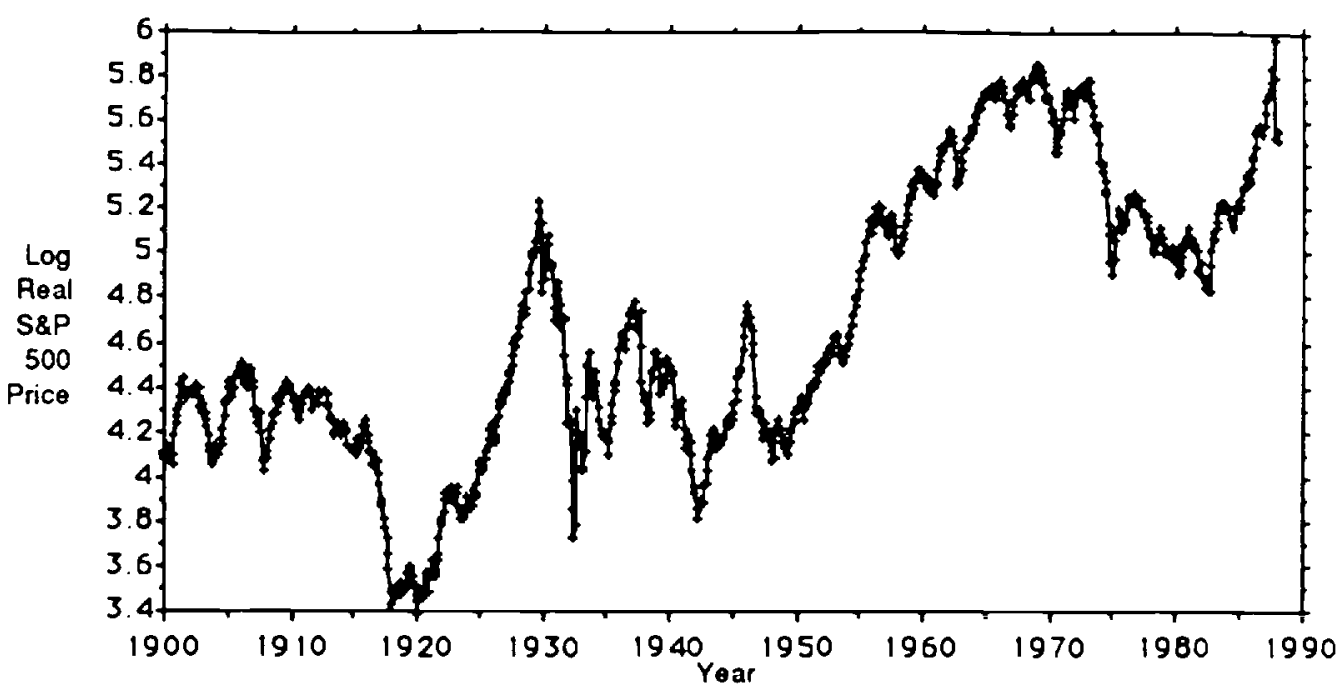

FIGURE 2

STOCK PRICES AND VALUE OF ACTUAL FUTURE DIVIDENDS PAID DETRENDED BY A THIRTY-

YEAR MOVING AVERAGE OF DIVIDENDS

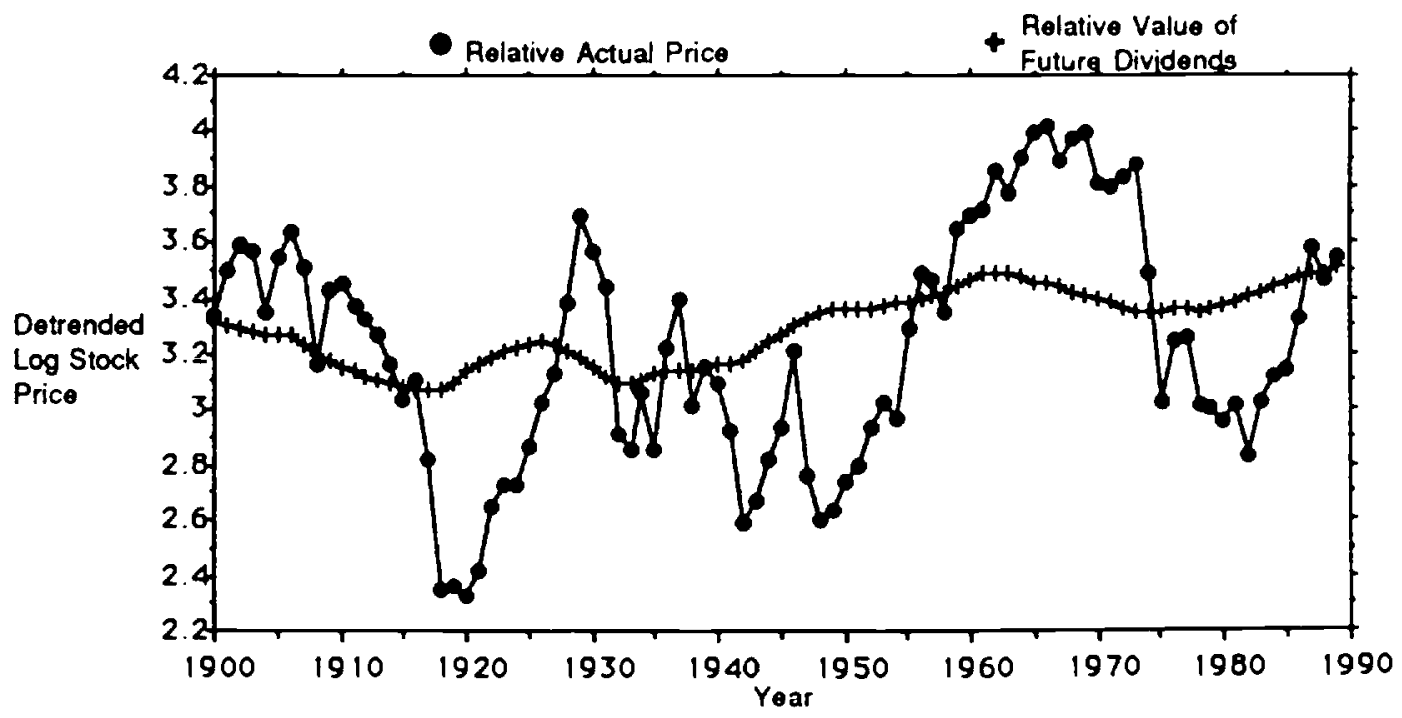


FIGUAE 3

YEAR-TO-YEAR DIVIDEND GROWTH

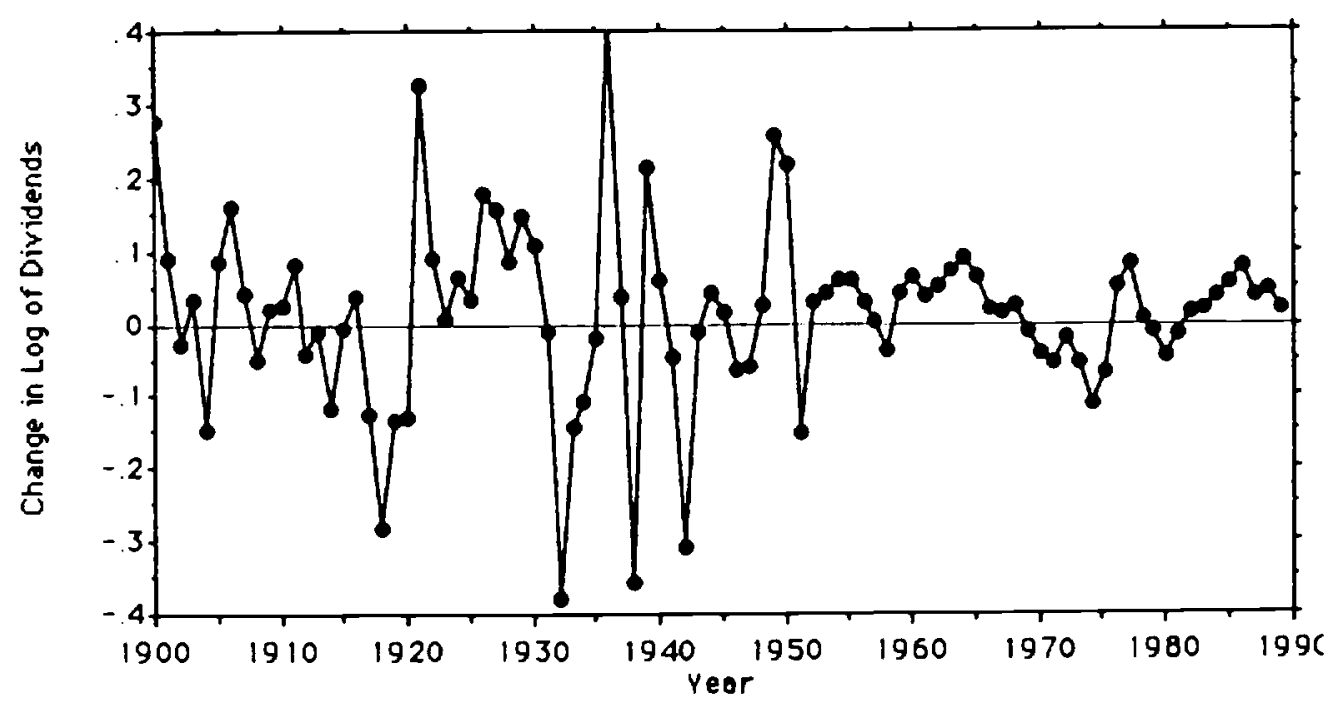

FIGURE 4

ACTUAL AND FITTED PRICES

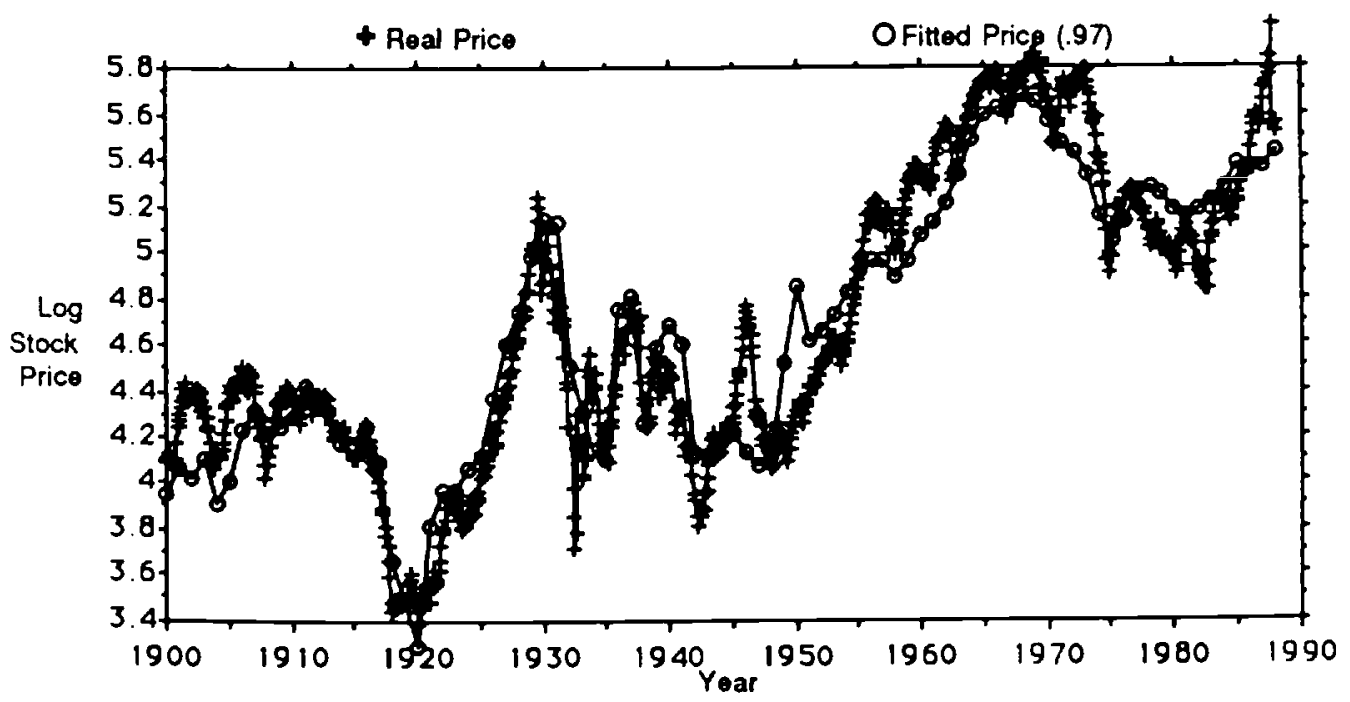


FIGURE 5

TWENTIETH CENTURY NOMINAL STOCK PRICES

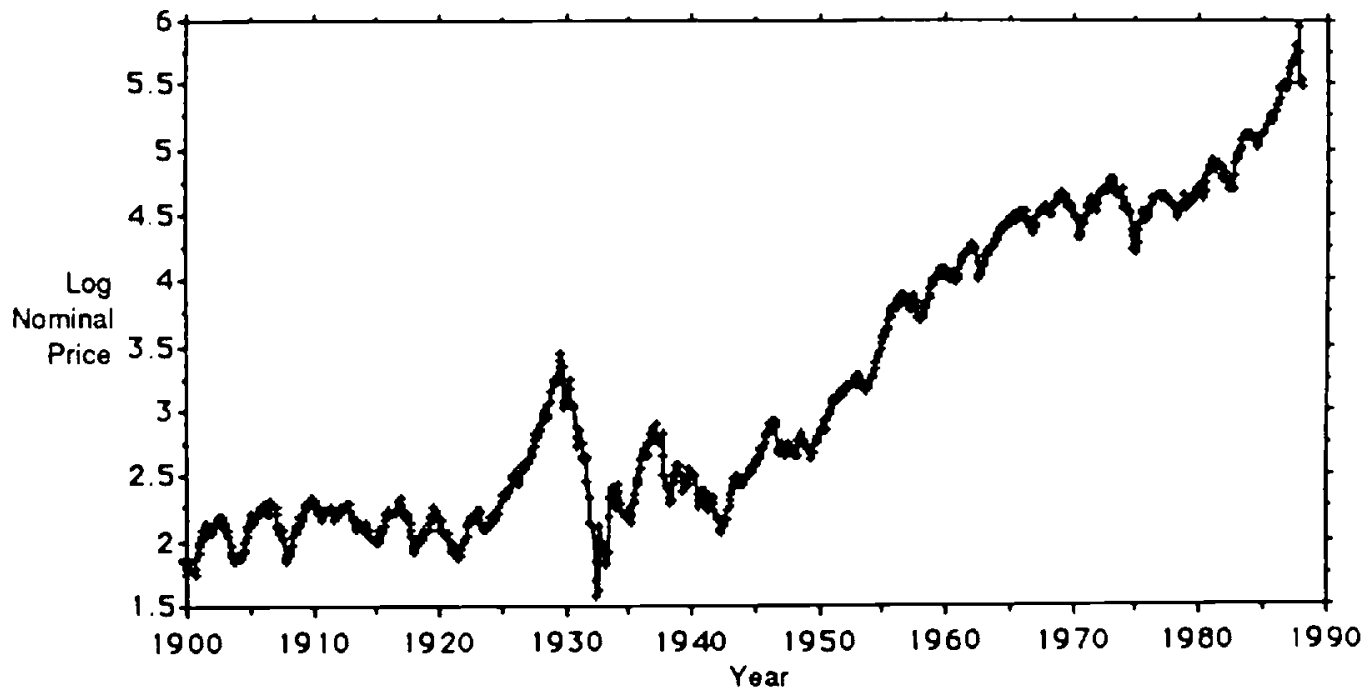

FIGURE 6

1950-80 RATES OF PER CAPITA INCOME GROWTH FOR SIXTY-TWO COUNTRIES

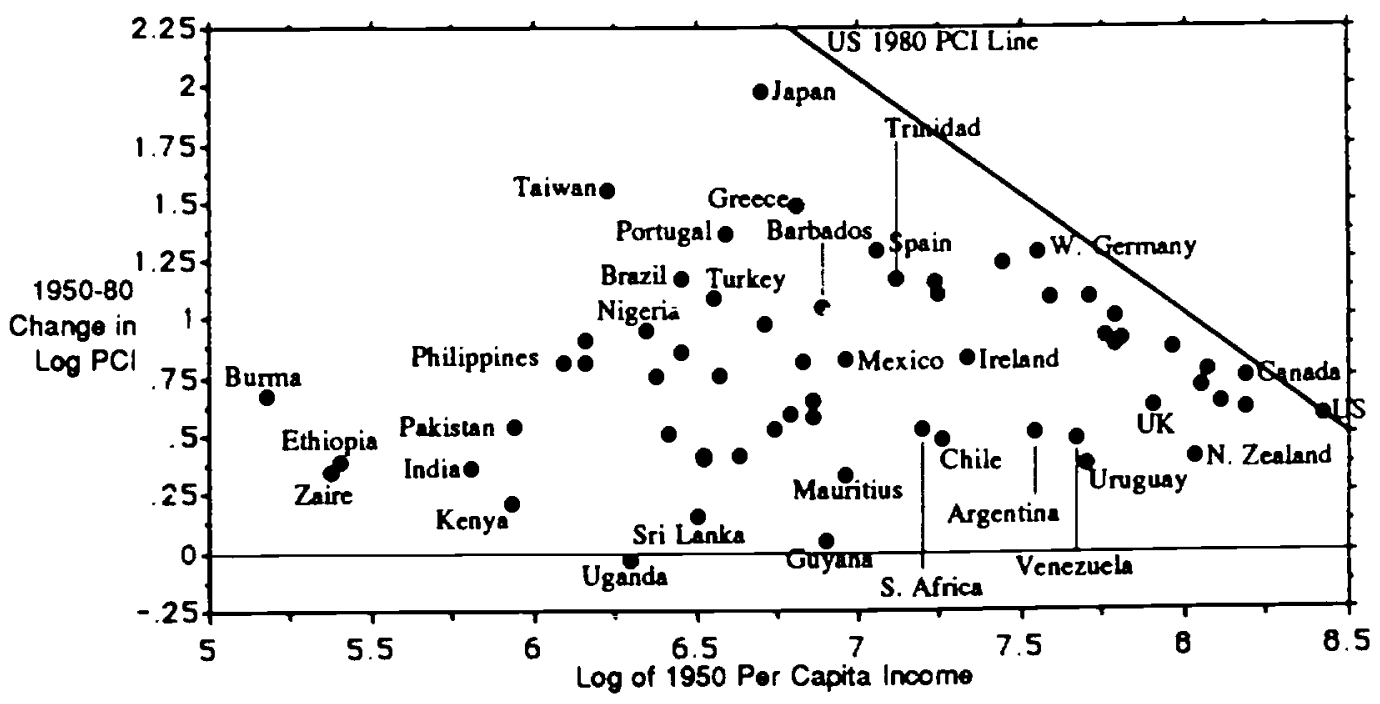




\section{Bull and Bear Markets}

TABLE 1

\section{SUMMARY STATISTICS FOR THE SIMPLE DIVIDEND-DISCOUNT MODEL}

\begin{tabular}{|c|c|c|c|}
\hline & Residual & Estimated & Estimated \\
\hline Model & Variance & $\underline{\delta}$ & $\underline{\theta}$ \\
\hline$\overline{\text { Fitted model }}$ & .0420 & .0003 & 0.97 \\
\hline $\begin{array}{l}\text { Constant estimate of dividend } \\
\text { growth }(\theta=1.00)\end{array}$ & .0609 & .0003 & set $=1.00$ \\
\hline $\begin{array}{l}\text { Constant rate of discount and } \\
\text { constant estimate of div- } \\
\text { dend growth }(\theta=1.00, r=\text { const })\end{array}$ & .0922 & set $=0$ & $s e t=1.00$ \\
\hline $\begin{array}{l}\text { Variance of price around actual } \\
\text { present value of future dividends }\end{array}$ & .1429 & NA & NA \\
\hline
\end{tabular}


The authors are Assistant Professors of Economics at the University of Michigan and Harvard University. respectively. They are also Faculty Research Fellows of the National Bureau of Economic Research. They wish to thank John Campbell, Barry Eichengreen, James Hamilton, Bruce Lehmann. Jeff Miron. Peter Lindert. Robert Shiller. Andrei Shleifer. and Arnold Zellner for helpful discussions.

1. Nominal stock index values are deflated by the producer price index. The index used is a smoothed monthly version of series 6 reported in the appendix to Robert Shiller, Market Volatility (Cambridge, Mass.: M.I.T. Press. 1989). The underlying nominal stock index prices used are monthly average values from various issues of the Security Price Index Record. published by the Standard \& Poor's Corporation. The S\&P price index was begun in 1926; the Cowles Commission. however. extended the index before 1926 back to 1870 . See Alfred Cowles et al.. Common Stock Indices. 2nd ed. (New York: Cowles Commission, 1939). We focus on twentieth century stock prices because the pre-1900 railroad-dominated market appears to us qualitatively different from the post-1900 industrials-dominated market. There is little reason to believe that price/dividend ratios and expected dividend growth rates should bear the same relation to each other as the market shifts from being $2 / 3$ railroads in 1890 to being $2 / 3$ industrials in 1910 . For the industrial composition of stock market indices. see Jack Wilson and Charles Jones, “A Comparison of Annual Common Stock Returns: 1871-1925 with 1926-1985." Journal of Business 60 (April 1987). pp. 239-58. For the rise of a market in industrial securities, see Lance Davis, "Capital Immobilities and Finance Capitalism: A Study of Economic Evolution in the United States," Explorations in Entrepreneurial History 1 (Fall 1963), pp. 88-105; and Vincent Carosso. The Morgans: Private International Bankers (Cambridge, Mass.: Harvard University Press, 1987).

2. The real GNP series used is spliced together from the revised estimates of GNP in different periods made by Christina Romer, and is discussed in J. Bradford De Long and Lawrence H. Summers, "How Does Macroeconomic Policy Affect Output?" Brookings Papers on Economic Activity 1988:2 (Fall 1988), pp. 433-80. 
3. Present values are calculated using a constant real discount rate of six percent. Figure 2 follows Robert Shiller's "Comovements in Prices and Comovements in Dividends," in his Market Volatility. In figure 2 it is assumed that the stock market's value in June 1989 accurately forecasts the present value of dividends to be paid in years after 1989.

4. See John Kenneth Galbraith, The Great Crash (Cambridge, Mass.: Riverside Press, 1954), Robert Sobel, The Big Board (New York: Free Press, 1965), John Maynard Keynes, The General Theory of Employment Interest and Money (London: Macmillan, 1936), especially chapter 12, and Robert Shiller, Market Volatility, especially the chapters previously published as "Stock Prices and Social Dynamics." Brookings Papers on Economic Activity 1984:2 (Fall 1984), pp. 457-98; and as "Do Stock Prices Move too Much to Be Justified by Subsequent Changes in Dividends?" American Economic Review 71 (1981), pp. 421-36.

5. See Robert Sobel, N.Y.S.E. (New York: Weybright and Talley, 1975). pp. 166-79.

6. A third view, popular among finance economists, is that stock prices always and everywhere equal the best available estimate of present fundamentals. The belief that the stock market was "the stage whereon is focused the world's most intelligent and best informed judgment of the values of... enterprises," and that no one has a better estimate of values than the stock market as a whole, was popular in the 1920's until the crash of 1929. For example, see Joseph S. Lawrence, Wall Street and Washington (Princeton, N.J.: Princeton University Press, 1929); Galbraith notes that after 1929 “Mr. Lawrence disappeared from Princeton. Among economists his voice was not heard again." The efficient market hypothesis did not become popular again until the 1960's.

7. John Campbell, "Estimating the Persistence of Expected Retums" (London School of Economics, unpublished, 1989) suggests that in the U.S. since 1926 fads and fashions have had an expected lifetime on the order of six months, not the five to ten years required if they are to account for major bull and bear swings.

8. Even if long swings in the stock market were primarily driven by fundamentals, sufficiently large short-run swings in stock prices could still lead to the conclusion that the economic per- 
formance of the stock market has been poor if marginal investors and firms follow short-run buy-and-sell rather than long-run buy-and-hold investment strategies. See J. Bradford De Long et al., "Noise Trader Risk in Financial Markets" (Harvard University, unpublished, 1987), and "The Size and Incidence of Losses from Noise Trading," Journal of Finance (1989).

9. Robert Shiller, "Comment on Miller and on Kleidon," in Robin Hogarth and Melvin Reder, eds., Rational Choice: The Contrast Between Economics and Psychology (Chicago: University of Chicago Press, 1987), pp. 285-315.

10. See John Burr Williams, The Theory of Investment Value (Cambridge, Mass.: Harvard University Press, 1937).

11. John Muth, in his essay "Optimal Properties of Exponentially Weighted Forecasts," Journal of the American Statistical Assocation 55 (1960), pp. 299-306, showed that this forecast rule (3) is the best that can be done using past rates of dividend growth if the rate of dividend growth is subject to independent and serially uncorrelated permanent and transitory shocks that have Gaussian normal distributions.

12. Equation (2) is used instead of equation (1) so that equal percentage deviations of prices from fitted values are counted equally in determining the fit of the model.

13. On this point, see also David Cutler et al., "What Moves Stock Prices?" Journal of Portfolio Management (Spring 1989), pp. 4-12.

14. Campbell, "Estimating the Persistence of Expected Returns," estimates that news about future cash flows accounts for about 30 percent only of the variation in month-to-month stock returns.

15. The 1980's have seen a swing in stock prices larger than can be accounted for in our model. We suspect that our model's failure to fit the Reagan bull market is due to the changing role of dividends. While before 1980 cash payments to shareholders besides dividends were trivial, they have made up a substantial part of shareholders' income in the 1980's. Our dividend series does not include these payments. See James Poterba, "Tax Policy and Corporate 
Saving," Brookings Papers on Economic Activity 1987:2 (Fall 1987), pp. 455-516.

16. Galbraith is more cautious. He sees the rise in stock prices through the end of 1927 as largely justifed by fundamentals, as does Gerald Sirkin, "The Stock Market of 1929 Revisited," Business History Review 49, 2 (Summer 1975): 233-41. Joel Seligman also agrees that "overspeculation" can only be said to have begun in the spring of 1928. See Joel Seligman. The Transformation of Wall Street (Boston: Houghton Mifflin, 1982).

17. See Sobel, The Big Board; Galbraith. The Great Crash; Charles Dice, New Levels in the Stock Market (New York: McGraw-Hill, 1929); and Lawrence, Wall Street and Washington.

18. Irving Fisher, The Stock Market Crash and After (New York: Macmillan, 1930).

19. An additional cause of rapid stock market growth in the 1920's may have been a general recognition that, in a turbulent time like the interwar period in which the long-run drift of the price level was uncertain. stocks were no more risky than bonds and yet promised higher expected retums. See Edgar L. Smith, Common Stocks as Long Term Investments (New York: Macmillan, 1924). The late 1920's also see the appearance of handbooks for investors that place great stress on valuing compound growth. For example, see Samuel Gould, Stock Growth and Discount Tables (Boston: Financial Publishing Company, 1931).

20. A few other voices, chosen more or less at random, reaching the same conclusion are Edgar Smith, Common Stocks as Long Term Investments (New York: Macmillan, 1924); K.S. von Strum, Investing in Purchasing Power (New York: Barron's, 1925); William Ripley, Main Street and Wall Street (New York: McGraw-Hill, 1927); Kimball, Russell, and Co., The Investment Problem-Its Solution (Boston: Kimball, Russell, and Co., 1928). After 1929 the view that the post-World War I boom would continue for a long time was easy to critique: see, for example, A.T. Miller, What to Consider When Buying Securities Today (New York: Ticker Publishing Co., 1932); Frederick Allen, Only Yesterday (New York: Harper and Brothers, 1931). But the view found few critics before 1929.

21. George P. Woodruff, Investment and Speculation (New York: Alexander Hamilton Institute, 1939). The lesson Woodruff drew from the ex ante reasonableness of confidence in the "New 
Era" and the subsequent catastrophe of the Depression was that one could have little confidence in any fundamental-based valuation of prices, for "the rationalizing of a price level, whether it is a high one or a low one, is one of the most insidious lures... whenever the papers are full or a rationalizing or explaining of high prices, the investor may take it as one cue to begin selling."

22. Galbraith. The Great Crash. p. 90.

23. Galbraith, The Great Crash, p. 20; Roger Babson, Business Barometers, 1930 ed. (Wellesley: Babson Institute, 1930), and Investment Fundamentals (New York: Harper and Brothers. 1930).

24. See Benjamin Graham and David Dodd, Security Analysis (New York: McGraw-Hill: 1st ed. 1934, 2nd ed. 1941); Benjamin Graham. The Intelligent Investor (New York: Harper and Row, 1st ed. 1954). Also see Warren Buffett's appendix to Benjamin Graham. The Intelligent Investor (New York: McGraw-Hill, 5th ed. 1987): John Train. The Money Masters (New York: Harper and Row, 2nd ed. 1987).

25. See Graham. The Intelligent Investor. Benjamin Graham, David Dodd. and Sidney Cottle. Security Analysis (New York: McGraw Hill, 4th ed. 1962).

26. Benjamin Graham and David Dodd, with the assistance of Charles Tatham, Security Analysis (New York: McGraw-Hill, 3d ed. 1951).

27. Graham was actually on the prudent end of commentary on the market in the early 1960 's. Others urged investors to pick "stocks for the surging 60 's." See Ira Cobleigh. A Guide to Success in the Stock Market (New York: Avon Books, 1961).

28. Louis Bean, How to Predict the Stock Market (Washington: Robert Luce, 1962).

29. Thomas Babson and David Babson, Investing for a Successful Future (New York: Macmillan, 1959).

30. Herschel Grossman, "The Political Economy of War Debts and Inflation" (Cambridge, Mass.: NBER Working Paper 2743, 1988).

31. See Peter Temin, Did Monetary Forces Cause the Great Depression? (New York: W.W. 
Norton and Company, 1976), and Lessons of the Great Depression (Cambridge, Mass.: M.I.T. Press, 1989), and Frederick Allen, Only Yesterday (New York: Harper and Brothers, 1931).

32. A.T. Miller, What To Consider When Buying Securities Today (New York: The Ticker Publishing Company, 1932).

33. Post-1929 U.S. economic growth does not show any noticeable slackening of pace

34. For example, Edgar L. Smith, Common Stocks as Long-Term Investments (New York: Macmillan Company, 1924).

35. Garfield Drew, New Methods for Profit in the Stock Market (Boston: Metcalf Publishing Co., 1948).

36. See Alvin Hansen, Economic Policy and Full Employment (New York: McGraw-Hill, 1947); Gottfried Haberler, Prosperity and Depression (New York: Atheneum, 1958).

37. Andrew Tobias, The Only Investment Guide You'll Ever Need (New York: Bantam Books, 1978).

38. See Walter Heller, New Dimensions of Political Economy (Cambridge, Mass.: Harvard University Press, 1965); James Tobin and Murray Weidenbaum, eds., Two Revolutions in Economic Policy (Cambridge, Mass.: M.I.T. Press, 1987).

39. On technical analysis, see "Adam Smith" [George Goodman], The Money Game (New York: Harper and Row, 1968).

40. Milton Friedman and Anna Jacobson Schwartz, A Monetary History of the United States (Princeton, NJ: Princeton University Press, 1963).

41. “Adam Smith" [George Goodman], Paper Money (New York: Harper and Row, 1981). Goodman, however, also accurately forecast that if the doomsday scenarios failed to come true, the 1980's "could be quite a party."

42. The data for figure 6 are drawn from Robert Summers and Alan Heston, "Improved Comparisons of Real Product and Its Composition, 1950-80," Review of Income and Wealth (1984): $207-61$. 